\title{
A BAC Library of the East African Haplochromine Cichlid Fish Astatotilapia burtoni
}

\author{
MICHAEL LANG ${ }^{1 \dagger}$, TSUTOMU MIYAKE ${ }^{2}$, INGO BRAASCH ${ }^{1}$, \\ DEBORAH TINNEMORE ${ }^{2}$, NICOL SIEGEL ${ }^{1}$, WALTER SALZBURGER ${ }^{1}$, \\ CHRIS T. AMEMIYA ${ }^{2 *}$, AND AXEL MEYER ${ }^{1 *}$ \\ ${ }^{1}$ Lehrstuhl für Zoologie und Evolutionsbiologie, Department of Biology, \\ University of Konstanz, 78457 Konstanz, Germany \\ ${ }^{2}$ Benaroya Research Institute at Virginia Mason, Seattle, Washington 98101
}

\begin{abstract}
A BAC library was constructed from Astatotilapia burtoni, a haplochromine cichlid that is found in Lake Tanganyika, East Africa, and its surrounding rivers. The library was generated from genomic DNA of blood cells and comprises 96,768 individual clones. Its median insert size is $150 \mathrm{~kb}$ and the coverage is expected to represent about 14 genome equivalents. The coverage evaluation was based on genome size estimates that were obtained by flow cytometry. In addition, hybridization screens with five probes largely corroborate the above coverage estimate, although the number of clones ranged from 5 to 22 authenticated clones per single copy probe. The BAC library described here is expected to be useful to the scientific community interested in cichlid genomics as an important resource to gain new insights into the rapid evolution of the great species diversity of haplochromine cichlid fishes. J. Exp. Zool. (Mol. Dev. Evol.) 306B:35-44, 2006.

(C) 2005 Wiley-Liss, Inc.
\end{abstract}

The species flocks of cichlid fishes of the East African Great Lakes Victoria, Tanganyika and Malawi are extraordinary examples for explosive speciation and adaptive radiation (Fryer and Iles, '72; Meyer et al., '90; Meyer, '93; Stiassny and Meyer, '99; Danley and Kocher, 2001; Turner et al., 2001; Kocher, 2004; Salzburger and Meyer, 2004). Each of the three lakes harbors several hundreds of endemic cichlid species that have evolved via intralacustrine speciation (speciation within the same lake). With an estimated number of about 1,700-2,000 species, the tribe Haplochromini represents, by far, the most species-rich assemblage of cichlid fishes. The entire species flocks of Lake Malawi and the Lake Victoria region superflock exclusively comprise haplochromines (Meyer, '93; Turner et al., 2001; Salzburger et al., 2002a, 2005; Verheyen et al., 2003; Salzburger and Meyer, 2004). The ages of these species flocks are dated at about 100,000 years for the Lake Victoria region superflock, and around 700,000 years for Lake Malawi (Meyer et al., '90; Kocher et al., '93; Danley and Kocher, 2001; Verheyen et al., 2003).

Molecular phylogenies have corroborated the derived status of haplochromines among the East African cichlid lineages, suggesting that the cichlid faunas of the Lake Victoria region and of Lake Malawi were seeded by generalists that inhabited rivers, swamp and marsh areas (Meyer et al., '91; Salzburger et al., 2002a, 2005; Verheyen et al., 2003).

The riverine haplochromine Astatotilapia burtoni (Günther, 1894) is thought to be a fitting representative of one of these potential founding lineages (Meyer et al., '91; Kocher et al., '93; Meyer, '93; Salzburger et al., 2002a; Verheyen et al., 2003). A . burtoni was shown to be a sister group to both the Lake Victoria region superflock and the Lake Malawi species flock, while its generalist life-style and body plan place it close to the proposed ancestral lineage (Meyer et al., '91) (Fig. 1).

\footnotetext{
Grant sponsors: Universität Konstanz and Deutache Forschungsgemeinschaft to Am; National Institute of Health and National Science Foundation to CTA; European Union (Marie Curie Individual Fellowship) and Landesstiftung Baden-Württemberg gGmbH

'Michael Lang's, current address is: Departament de Genètica, Universitat de Barcelona, 08028 Barcelona, Spain.

*Correspondence to: Axel Meyer, Lehrstuhl für Zoologie und Evolutionsbiologie, Department of Biology, University of Konstanz, 78457 Konstanz, Germany. E-mail: axel.meyer@uni-konstanz.de

*Correspondence to: Chris T. Amemiya, Benaroya Research Institute at Virginia Mason, Seattle, Washington 98101.

E-mail: camemiya@benaroyaresearch.org

Received 13 February 2005; Accepted 20 June 2005

Published online 27 October 2005 in Wiley InterScience (www. interscience.wiley.com). DOI: 10.1002/jez.b.21068.
} to WS. 


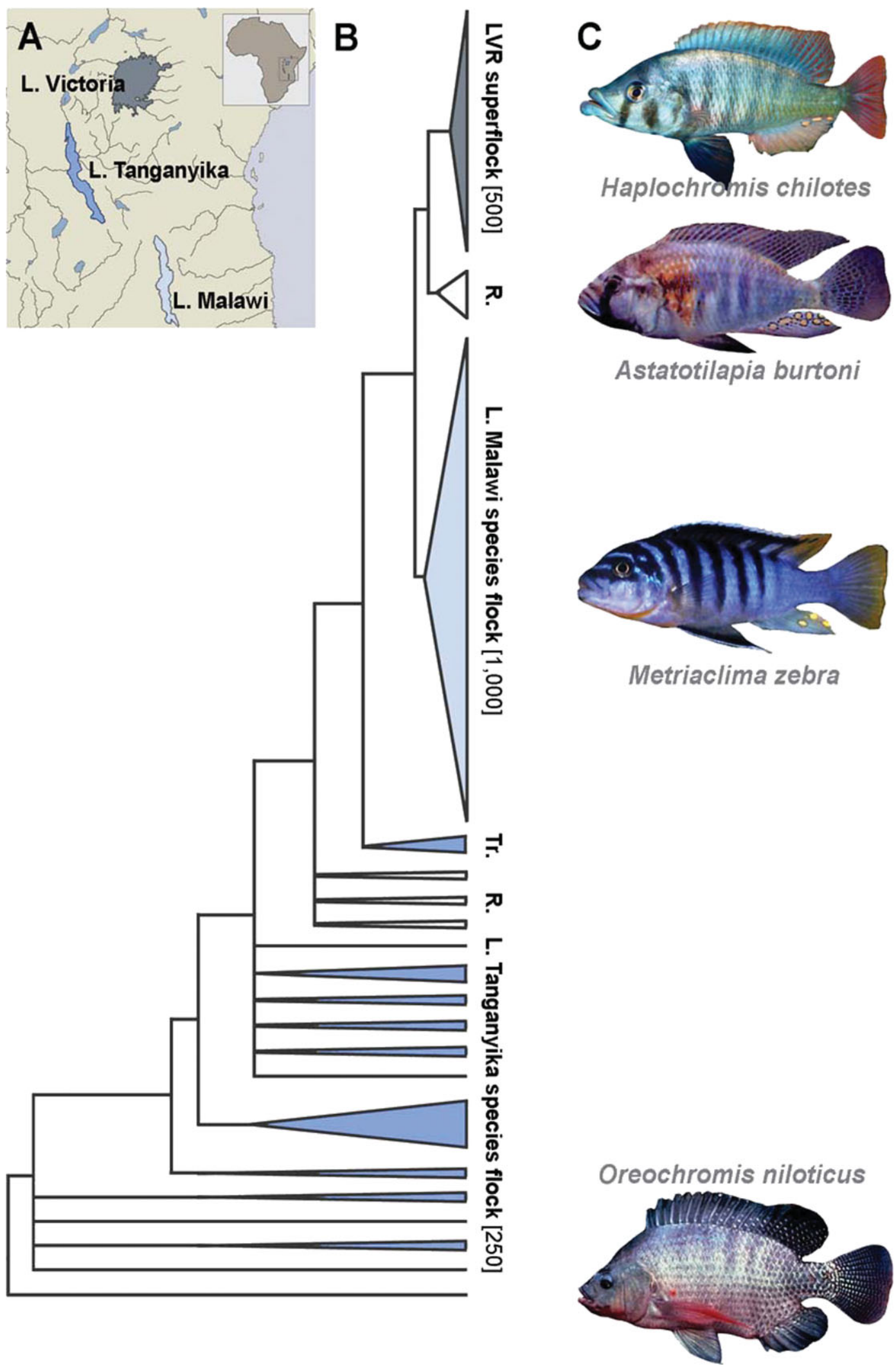


Besides being a popular model species in evolutionary biology, A. burtoni is also used in neuroethological studies (Wickler, '62; Francis et al., '93; Hofmann et al., '99). Territorialism and breeding behavior of males is strongly dependent on their current social status, which often changes within weeks. This is accompanied by alteration of coloration, growth and size of corresponding neural cells (Hofmann and Fernald, 2000).

Currently, several projects seek to gain new insights into the genomic and molecular biological bases for the adaptive evolution of haplochromine cichlids. EST projects (http://www.tigr.org/tdb/tgi/) (Watanabe et al., 2004) and microarray studies promise to detect differentiation in gene expression patterns (Renn et al., 2004). QTL mapping has already identified genomic regions important for jaw morphologies and coloration phenotypes of the Lake Malawi cichlid Metriaclima zebra (Albertson et al., 2003; Streelman et al., 2003). Recently, a genome sequencing consortium has been established in an effort to propose sequencing of the Nile tilapia Oreochromis niloticus genome (Kocher et al., 2004).

BAC libraries (Shizuya et al., '92; Miyake and Amemiya, 2004) are essential resources for the analyses of extended genomic regions or entire genomes of higher organisms. Once prepared from a species of interest, genomic regions of about $150 \mathrm{~kb}$ length are stably preserved and accessible by conventional library screening methods.

So far, BAC libraries of the Nile tilapia O. niloticus (Katagiri et al., 2001) and of the Lake Victoria cichlid Haplochromis chilotes (Watanabe et al., 2003) have been constructed. Moreover, a BAC library of the Malawi cichlid M. zebra is available at the Hubbard Center for Genome Studies (http://hcgs.unh.edu/BAC/Metriaclima.html). The latter two species provide genome resources from haplochromines from the Lake Victoria region superflock and the Lake Malawi species flock, respectively. Comparative studies that include these highly specialized haplochromines and the generalist $A$. burtoni promise to be informative with regard to the underlying genetic mechanisms that led to the enormous degree of diversification observed in cichlids within such a short time. It has been shown in previous work (see, e.g., Zardoya et al., '96; Salzburger et al., 2002b) that it is possible to obtain DNA sequence data of a large phylogenetic spectrum in cichlids. This could be achieved by application of standard PCR protocols with primers designed in non-coding nuclear DNA regions. Hence, DNA sequence data of many cichlid species should be easily obtained, once having detected the corresponding DNA region by BAC library screening of only one species (e.g., A. burtoni).

Here we describe the construction of a BAC library for A. burtoni. It is an arrayed BAC library that comprises approximately $14 \times$ coverage of the genome and a median insert size of $150 \mathrm{~kb}$.

\section{MATERIALS AND METHODS}

\section{High molecular weight DNA extraction}

Specimens of $A$. burtoni were reared under laboratory conditions in aquaria ( $12 \mathrm{hr}$ light; $12 \mathrm{hr}$ dark). Genomic DNA was obtained from the arterial blood of one male A. burtoni (approximately $8 \mathrm{~cm}$ head to tail length) from an inbred strain, following Amemiya et al. ('96). The specimens were sacrificed after anesthetization with MS222, cooled in ice-water and the blood was collected from the dorsal aorta posterior of the insertion of the dorsal fin. A $1 \mathrm{ml}$ syringe (needle gauge 27) was used and the blood was collected $2 \mathrm{~min}$ after injection of $30 \mu \mathrm{l}$ heparin, $100 \mathrm{mg} / \mathrm{ml}$. The blood obtained was further mixed with onefourth volume of heparin, $100 \mathrm{mg} / \mathrm{ml}$, and the blood cell concentration was then estimated with a hemacytometer (Neubauer Improved) from 1:100 dilutions in $0.85 \times$ PBS. Aliquots of cells were diluted in $0.85 \times$ PBS, mixed with Incert Agarose (Cambrex Bio Science, Baltimore, MD) and poured into $80 \mu \mathrm{l}$ plug molds (BioRad Laboratories, Hercules, CA), giving a final agarose concentration of $1 \%$. Plugs were treated overnight at room

Fig. 1. BAC libraries of East African cichlid fishes. (A) Map of East Africa showing the three Great Lakes Victoria, Tanganyika and Malawi. (B) Mitochondrial phylogeny of the East African cichlids modified from current phylogenies (Klett and Meyer, 2002; Salzburger et al., 2002a; Verheyen et al., 2003; Salzburger and Meyer, 2004). The cichlid species flock from Lake Tanganyika is the oldest and genetically most diverse. Some riverine cichlid lineages (R.) and the Tanganyikan Tropheini (Tr.) are sister to the Lake Malawi cichlid species flock, another riverine clade (R.) including Astatotilapia burtoni, and the Lake Victoria region (LVR) superflock. The sizes of the clades represent the respective species numbers. Species number for the three large assemblages are depicted in square brackets. (C) BAC libraries are currently available for four cichlid species: $H$. chilotes from Lake Victoria (Watanabe et al., 2003), Metriaclima zebra from Lake Malawi (http://hcgs.unh.edu/BAC/Metriaclima.html), Astatotilapia burtoni (present study) and the Nile tilapia Oreochromis niloticus (Katagiri et al., 2001). 
temperature in cell lysis solution ( $1 \% \mathrm{LDS}, 10 \mathrm{mM}$ Tris $\mathrm{pH}$ 8.0, $100 \mathrm{mM}$ EDTA $\mathrm{pH} 8.0$ ). The solution was substituted several times. Finally, plugs were stored in $20 \%$ NDS $(0.2 \% N$-laurylsarcosine, $2 \mathrm{mM}$ Tris pH 9.0, 0.14 M EDTA pH 9.0). Before further treatment, pulsed-field-gel-electrophoresis (BioRad, XA Mapper) was used to discard low molecular weight DNA from the plugs.

\section{BAC library construction}

For size fragmentation, genomic DNA of each plug was partially digested for $2.5 \mathrm{hr}$ in $500 \mu \mathrm{l}$ reaction volumes containing the restriction enzyme EcoRI (New England Biolabs, Ipswich, MA) and EcoRI methylase (New England Biolabs). The optimal quantities of enzyme activity had to be estimated previously by titration experiments employing $1 / 6$ plug per sample. Other components were $2.6 \mathrm{mM}$ spermidine, $0.5 \mathrm{mg} / \mathrm{ml}$ BSA (New England Biolabs) and reaction buffer $(0.08 \mathrm{mM} S$ adenosylmethionine, $2 \mathrm{mM} \mathrm{MgCl} 2,100 \mathrm{mM} \mathrm{NaCl}$, $50 \mathrm{mM}$ Tris-Cl, $1 \mathrm{mM}$ DTT). The reaction was stopped with $150 \mu \mathrm{l}$ of a solution containing $300 \mu \mathrm{g}$ proteinase K, $2.9 \% \mathrm{~N}$-laurylsarcosine and $0.29 \mathrm{M}$ EDTA, followed by an incubation at $37^{\circ} \mathrm{C}$ for $1 \mathrm{hr}$. Proteinase $\mathrm{K}$ activity was inhibited by addition of $12 \mu \mathrm{l} \mathrm{PMSF}, 100 \mathrm{mM}$. DNA fragments were separated on a $1 \%$ agarose gel using pulsed-fieldgel-electrophoresis (BioRad CHEF XA Mapper), essentially as described by Osoegawa et al. ('98). Gel slices were prepared that contained size fragments of high molecular weight and the DNA fragments were electroeluted and dialyzed according to Strong et al. ('97) and Danke et al. (2004). A small fraction of the high molecular weight DNA was analyzed on a $1 \%$ agarose gel and the DNA concentration was estimated by comparison with defined amounts of the DNA standard size ladder $\lambda$-HindIII. The Copy Control ${ }^{\mathrm{TM}}$ Kit (Epicentre, Madison, WI) was used for ligation reactions. Approximately $50 \mathrm{ng}$ of partially digested DNA and $25 \mathrm{ng}$ of the BAC vector CopyControl ${ }^{\mathrm{TM}}$ pCC1BAC $^{\mathrm{TM}}(E c o R I)$ were ligated in $50 \mu \mathrm{l}$ reaction volumes that were carried out overnight at $15^{\circ} \mathrm{C}$.

After ligation, samples were inactivated by a brief proteinase $\mathrm{K}$ treatment, desalted by drop dialysis against $\mathrm{ddH}_{2} \mathrm{O}$ for $2 \mathrm{hr}$ using $0.025 \mu \mathrm{m}$ nitrocellulose filters (Millipore, Billerica, MA) and the sample volume was then reduced three-fold by drop dialysis against PEG8000 (30\% in $1 / 2 \times \mathrm{TE}$ ). For test transformations, approximately $15-20 \mathrm{ng}$ DNA of desalted ligation mix was added to $20 \mu \mathrm{l}$ electrocompetent cells DHB10T1 (Invitrogen,
Carlslbad, CA). Electroporation was carried out with the Cell-Porator Escherichia coli Pulser (Gibco-BRL, Invitrogen) with subsequent incubation of cells in $500 \mu \mathrm{l}$ SOC for $1 \mathrm{hr}$ at $37^{\circ} \mathrm{C}$ at $250 \mathrm{rpm}$. For large-scale transformations, approximately 75-100 ng DNA was added to one vial $(\sim 100 \mu \mathrm{l})$ of electrocompetent cells. Electroporation was performed with the Electro Cell Manipulator 600 (BTX, Harvard Apparatus, Inc., Holliston, MA) and $2 \mathrm{~mm}$ cuvettes (M $\beta \mathrm{P}$, San Diego, CA, USA) applying $2.5 \mathrm{kV}$ pulses. After expressing in $5.0 \mathrm{ml} \mathrm{SOC}$ for $1 \mathrm{hr}$ at $37^{\circ} \mathrm{C}$, glycerol was added to the transformation mix to a final concentration of $10 \%$. Small aliquots were removed (for titering the number of colonies in the transformed material) and the rest snap-frozen with liquid nitrogen and stored at $-80^{\circ} \mathrm{C}$.

\section{Insert size estimation}

Test amounts of transformation mix were grown on LB agar plates $(12.5 \mu \mathrm{g} / \mathrm{ml}$ chloramphenicol, $0.4 \mathrm{mM}$ IPTG and $40 \mu \mathrm{g} / \mathrm{ml}$ XGAL). Clones were isolated randomly and prepared manually using a modification of a standard plasmid miniprep protocol (Sambrook and Russell, 2001). A tenth of each prepared BAC clone DNA was digested with the restriction enzyme NotI (Invitrogen) and the samples were then analyzed on a pulsed-field gel. The size of each clone was estimated manually using low-range PFG markers (New England Biolabs) as references.

\section{Genome size estimation}

Arterial blood was obtained as described above. A volume of $50 \mu \mathrm{l}$ blood was obtained from one male specimen and mixed with $450 \mu \mathrm{l}$ Liquemin N25000 (F. Hoffmann-LaRoche Ltd., Basel, Switzerland) and stored at room temperature. Cells were washed and prepared as described in Danke et al. (2004); chicken red blood cell nuclei were used as internal standards. Genome sizes were estimated through flow cytometry (FACSCalibur, Becton-Dickinson, Franklin Lakes, NJ).

\section{Library arrays}

To array the library, the transformed cells were grown on LB agar plates $(12.5 \mu \mathrm{g} / \mathrm{ml}$ chloramphenicol, $0.4 \mathrm{mM}$ IPTG and $40 \mu \mathrm{g} / \mathrm{ml}$ XGAL) and single white colonies were transferred into 384well microtiter plates (Genetix M7001) using a colony-picking robot (Norgren Systems, Littleton, $\mathrm{NH}$ ). A total array system (Biorobotics, Cambridge, MA) was used for library replication and 
to prepare nylon filter sets $(22 \times 22 \mathrm{~cm})$, containing BAC colony DNAs.

\section{Library screening}

One nylon filter set was hybridized overnight in $0.6 \mathrm{M} \mathrm{NaCl}, 0.02 \mathrm{M}$ EDTA, 0.2 M Tris pH 8.0, 0.5\% SDS and $0.05 \%$ sodium pyrophosphate at $65^{\circ} \mathrm{C}$ with gene-specific DNA probes that ranged in size from 277 to $725 \mathrm{bp}$. The probes for five genes were amplified with gene-specific primers (Table 1) and labeled with $\alpha^{32} \mathrm{P}$-dCTP by random priming (Feinberg and Vogelstein, '83). The filters were washed in wash buffer $(1 \times \mathrm{SSC}, 0.1 \%$ SDS, $0.05 \%$ sodium pyrophosphate) for $30 \mathrm{~min}$ at room temperature and then for $40 \mathrm{~min}$ at $37^{\circ} \mathrm{C}$. DNAs from resultant positive clones were isolated and prepared according to the FastPlasmid Mini Kit (Eppendorf, Hamburg, Germany) or manually as explained above. The clones were further analyzed by PCR and direct sequencing on an ABI 3100 automated capillary DNA sequencer using the Big Dye Termination Reaction chemistry and genespecific primers. In some cases, positive hybridizing clones were re-spotted on nylon filters and screened once more with gene-specific probes. Resultant positive clones were prepared manually and analyzed by PCR for validation. Restriction digestions of positive clones were prepared with the restriction endonucleases NotI and EcoRI, followed by pulsed-field gel electrophoresis or standard gel electrophoresis, respectively.

\section{Phylogenetic reconstruction}

A neighbor-joining tree of Sox10 protein sequences from several vertebrate taxa was recon- structed applying the gamma model in MEGA2 (Kumar et al., 2001). The obtained phylogeny was assessed by bootstrapping (5,000 replicas). The tree was rooted with human SOX9. GenBank accession numbers for the sox10 sequences are given in Fig. 3A and Table 1.

\section{RESULTS AND DISCUSSION}

We extracted genomic DNA from the arterial blood of one male $A$. burtoni from an inbred strain. A total of $600 \mu$ l of blood with heparin was obtained from the specimen. The blood cell concentration was quantified to be approximately $10^{9}$ cell $\mathrm{s} / \mathrm{ml}$ and quantities corresponding to $1 \times 10^{7}$ cells were poured into $80 \mu \mathrm{l}$ agarose plugs. The obtained amount of DNA in the plugs was approximately $20 \mu \mathrm{g}$. Titration experiments were carried out to optimize size fragmentation of genomic DNA with the restriction endonuclease $E c o$ RI and EcoRI methylase. We used 1/6 plug and variable amounts of EcoRI restriction enzyme (1-6 units) and EcoRI methylase (10-60 units) for each sample in a $500 \mu \mathrm{l}$ reaction volume. The goal was to obtain a tight, yet homogeneous distribution of partially digested DNA upon analytical pulsedfield gel electrophoresis. Based on this titration, five agarose plugs containing genomic DNA (approx. $150 \mu \mathrm{g}$ ) were partially digested for $2.5 \mathrm{hr}$ with 4 units EcoRI and 50 units EcoRI methylase. DNA fragments were separated by preparative pulsed-field gel electrophoresis and several gel slices were prepared that contained partially digested DNA fragments, ranging from 50 to $250 \mathrm{~kb}$. Test ligations and transformations with the various fractions revealed that a particular

TABLE 1. List of genes used for screening the BAC library, including gene-specific primers, the location of the primers on the gene, the length of the probe, GenBank accession numbers for gene sequences in Astatotilapia burtoni, and number of positive clones after PCR verification

\begin{tabular}{|c|c|c|c|c|c|}
\hline Gene & Primer sequence & Location & Probe length & $\begin{array}{l}\text { No. of positive } \\
\text { BAC clones }\end{array}$ & Accession number \\
\hline \multirow[t]{2}{*}{ tfap $2 a$} & F: $5^{\prime}$-CAA AGA GTT CAC RGA CCT GCT G-3' & Exon 7 & $277 \mathrm{bp}$ & 6 & AY970938 \\
\hline & R: 5' -CTT TCT GTG CTT CTC RTC TTT GTC-3' & Exon 7 & & & \\
\hline \multirow[t]{2}{*}{$m c 1 r$} & F: $5^{\prime}$-SGC GGA YCG YTA YAT CAC CA- $3^{\prime}$ & Exon 1 & $486 \mathrm{bp}$ & 21 & AY970939 \\
\hline & R: $5^{\prime}$-TCC TGR CTS CGG TAV GCG TA- $3^{\prime}$ & Exon 1 & & & \\
\hline \multirow[t]{2}{*}{ ednrb1 } & F: 5' -AAR GAY TGG TGG CTK TTC AG-3' & Exon 4 & $725 \mathrm{bp}$ & 18 & AY970945 \\
\hline & R: 5' -GAK GCC ATG TTG ATS CCA AT-3' & Exon 6 & & & \\
\hline \multirow[t]{2}{*}{ aim1 } & F: 5' -CTG GGM GGA GCW TGT GGT TAC-3' & Exon 3 & $322 \mathrm{bp}$ & 5 & AY970940 \\
\hline & R: $5^{\prime}$-TGG CTT CWC CSA GRG CWG AGA A- $3^{\prime}$ & Exon 3 & & & \\
\hline \multirow[t]{4}{*}{ sox10b } & F: $5^{\prime}$-CCW ACC ACY CCC AAG ACS GAA C- $3^{\prime}$ & Exon 3 & $659 \mathrm{bp}$ & $22(\operatorname{sox} 10 b)$ & AY970944 \\
\hline & R: $5^{\prime}$-CCC ATR TAR GAG AAG GCR GAG T-3' & Exon 3 & & $15(\operatorname{sox} 10 a)$ & AY970942 \\
\hline & F: 5' -GAG GAG CAS AGC WTK TCG GAG-3' & Exon 1 & PCR/seq. only & & AY970941 (sox10a) \\
\hline & R: 5' -ASA GCT TCC CCA GYG TYT TGC-3' & Exon 1 & & & AY970943 (sox10b) \\
\hline
\end{tabular}


DNA fraction with an average size of $150 \mathrm{~kb}$ yielded $\sim 2400$ recombinant BAC clones per $1 \mu \mathrm{l}$ of DNA solution. Given the total volume of $150 \mu \mathrm{l}$ of the partial digest DNA solution, this fraction could have potentially yielded about 360,000 recombinant clones and thus was used for library construction.



Fig. 2. Size distribution of BAC clone inserts. A total of 162 randomly picked clones were prepared and digested with the restriction enzyme NotI. Samples were run on a CHEF gel and insert sizes were calculated manually by comparison with standard size markers.
A total of 162 clones were isolated randomly from the transformed bacterial material in order to assess the distribution of clone insert lengths of the library. DNAs from respective clones were digested with the restriction endonuclease Not I and analyzed on a pulsed-field gel. The size of each clone was estimated manually using a standard pulsed-field DNA size marker (New England Biolabs, Low Range Marker) as reference.

The clone insert size had a mean of $145 \mathrm{~kb}$ and a median of $150 \mathrm{~kb}$ (Fig. 2). The insert size distribution obtained fits well with the DNA insert sizes that were used in the cloning procedure. The portion of clones that were smaller than $100 \mathrm{~kb}$ was estimated to be about 10\%; one clone (out of 162) did not contain any insert.

The genome size of $A$. burtoni was estimated in order to obtain a reference value for assessing the completeness and the genomic coverage of the BAC library. Several studies with closely related species suggested the genome size to be $1.0-1.2 \mathrm{pg}$ per haploid genome (Hinegardner and Rosen, '68, '72; see also Ohno and Atkin, '66; Majumdar and McAndrew, '86; Vinogradov, '98; Gregory, 2001). However, to obtain a confident estimate, we
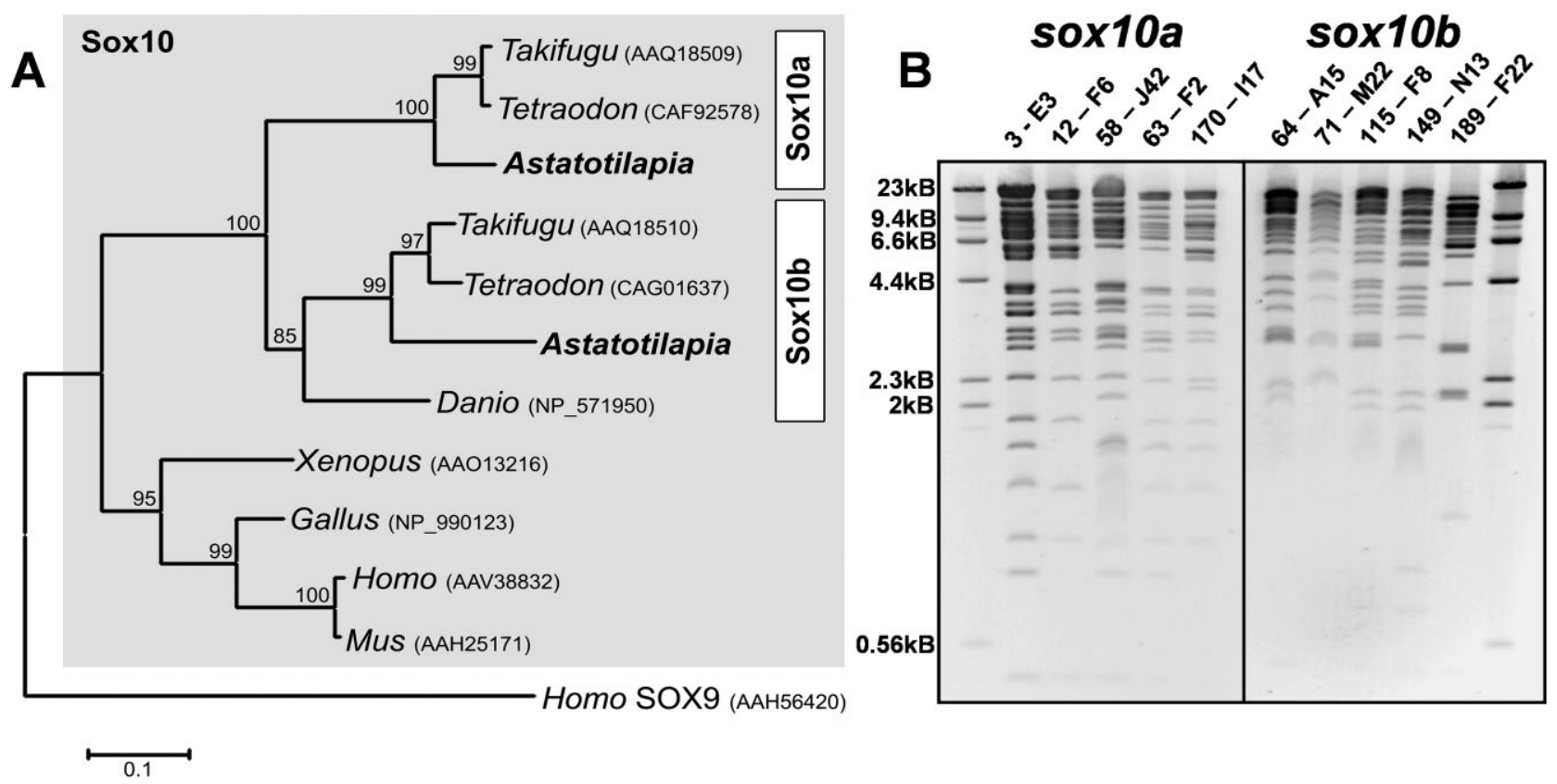

Fig. 3. Characterization of sox10a or sox10b containing BAC clones. (A) Phylogeny of vertebrate Sox10. A neighbor-joining tree of Sox10 protein sequences from several vertebrate taxa. Numbers above nodes indicate bootstrap values (5,000 replicas). The tree was rooted with human SOX9. The cichlid Sox10 paralogs (corresponding to the concatenated sequences of exons 1 and 3 ) are depicted in bold. Sox10 terminology is adapted from Koopman et al. (2004). The zebrafish Sox10 paralog with a function in pigment cell development (Dutton et al., 2001) belongs to the Sox10b branch. (B) Agarose gel (1\%) with EcoRI restriction digestions of ten BAC clones containing sox10a or sox10b, and the DNA size standard Lambda-HindIII. The restriction patterns of sox $10 \mathrm{a}$ and sox $10 \mathrm{~b}$ clones are clearly distinct, confirming that the sox10 paralogs are located in different genomic regions. 
measured the genome size of $A$. burtoni red blood cells of one male specimen, using flow cytometry. In agreement with the previous studies, a value of $0.97 \mathrm{pg}$ per haploid genome was estimated from measurement of several thousand cells in two separate flow cytometer experiments (data not shown). This value is only slightly below the range of genome sizes of other cichlid fish species (see above). Actually, a wide variance is also found by comparing different genome size estimates for a single species, the Nile tilapia $O$. niloticus, ranging from 0.95 to $1.2 \mathrm{pg}$ per haploid genome (Gregory, 2001). Thus, we cannot see any discrepancy of the genome size estimate of $A$. burtoni to the estimates of closely related species.

A total of 96,768 clones were isolated into 384well microtiter dishes, comprising an estimated $14 \times$ coverage of the A. burtoni genome. Two replicas of the library were prepared, and an approximate $13 \times$ fraction of the library was spotted onto $22 \times 22 \mathrm{~cm}$ nylon hybridization membranes.

The depth of the library was independently corroborated by screening the BAC library filter set with gene-specific probes for five genes. The complete nylon filter set was screened with two or three different probes per screen that were specific to the genes aim1, tfap2, mc1r, ednrb1 and sox10b. Further verification of hybridizing clones was obtained by PCR amplification with gene-specific DNA sequences and direct sequencing of the obtained PCR products. The screens for aim 1 and tfap 2 were additionally verified by re-spotting positive clones on nylon membranes for a second hybridization with the corresponding probes. Strong hybridizing clones were prepared and re-analyzed by PCR. In this way, a more thorough detection of true positives was obtained.

The genes that were analyzed in our study play important roles at different developmental levels of teleost color patterning: tfap $2 a$ is required for early steps in the development of the neural crest, from which pigment cells are derived (Knight et al., 2003). sox10b further specifies the nonectomesenchymal neural crest derivatives including pigment cells (Dutton et al., 2001; Koopman et al., 2004). ednrb1 is not only expressed by different pigment cell types but also has a patterning function since loss-of-function mutations lead, for example, to disrupted adult stripes in zebrafish (Parichy et al., 2000). mc1r and aim1 are important for the differentiation of the dark pigment cells, the melanin-producing melano- phores. While $m c 1 r$ has a role in melanin regulation (Barsh, 2003), aim1 is thought to be involved in melanin synthesis (Fukamachi et al., 2001). Since the diversification of color patterns has played an important role in the adaptive radiations of East African lake cichlids (Meyer, '93; Danley and Kocher, 2001; Allender et al., 2003; Terai et al., 2003), these genes represent candidate "speciation genes".

The screens for $m c 1 r$ and ednrb1 revealed 21 and 18 positive clones, respectively. In comparison with the estimated filter coverage of 13 times the A. burtoni genome, these results suggest an overrepresentation of the corresponding genomic regions since PCR amplification and direct sequencing of the positive clones revealed identical DNA sequences (i.e., belonged to the same gene).

Recently, it was shown that sox10 is duplicated in the pufferfish Takifugu rubripes and the two copies were named sox10a and sox10b (Koopman et al., 2004). This finding could be confirmed for A. burtoni. DNA sequence comparisons discriminated between 15 sox10a- and 22 sox $10 b$-specific clones out of the total of 37 positives. The probe for the screen was designed from a region of exon 3 of sox $10 b$ and the deduced amino acid sequences of both obtained gene fragments revealed uninterrupted open reading frames.

Phylogenetic reconstruction of the sox10 gene fragments indicates that they are sox10a and sox10b, as defined by Koopman et al. (2004) (Fig. 3A). In addition to the obtained $659 \mathrm{bp}$ sox10 exon 3 DNA fragments, a $424 \mathrm{bp}$ section of sox10 exon 1 coding sequence was amplified and sequenced directly from each clone with genespecific primers (Table 1). The concatenated DNA sequences, including published data, were used for phylogeny reconstruction (Fig. 3A) and the obtained gene tree shows that the duplication of the sox10 gene is older than the split of the lineages of Ostariophysi (represented by zebrafish) and Neoteleostei (represented by fugu and cichlid). In contrast to tetrapods, ray-finned (actinopterygian) fishes have undergone a whole genome duplication early in teleost evolution (see, e.g., Taylor et al., 2003). It is, therefore, most likely that sox10 was duplicated during this genome duplication event. The $E c o R I$ fingerprint patterns of five positive clones each for sox10a and sox10b are shown in Fig. 3B. The restriction fragment patterns are clearly distinct between the two duplicates, indicating that the genes are located in different genomic regions.

In our BAC screens, we recovered two paralogous copies of sox10 gene fragments while the 
DNA probe was designed on the paralog sox10b. This is noteworthy, since the $659 \mathrm{bp}$ DNA sequences that correspond to the probe differ by almost $30 \%$ between the two paralogous gene fragments. Given the hybridization conditions of our screens (see Materials and Methods), this shows that the screening of BAC clones proves to be a powerful tool to identify paralogous genes. In this case, the corresponding duplication event should have occurred more than 300 million years ago (Taylor et al., 2003).

The expression of sox $10 a$ and sox $10 b$ in A. burtoni remains to be analyzed with respect to tissue specificity and developmental stage. This could give important information about the probable function of the two genes, especially of sox10a, for which no such information is available.

The EcoRI fingerprint patterns of digested BAC clones (Fig. 3B) demonstrated that the clones do indeed result from partially digested genomic DNA and as a consequence are expected to contain essentially random areas of the genome and, hence, are overlapping. Therefore, this BAC library can be employed to obtain overlapping $\mathrm{BAC}$ clones for regional analysis of a given genomic region.

The screens for aim 1 and tfap2 confirmed five and six positive clones, respectively. These comparatively low numbers of detected clones indicate that there is some variation in the coverage of the library. Noteworthy, the probes that were employed for screening for aim 1 and tfap 2 were, by far, the shortest ones with lengths of $322 \mathrm{bp}$ (aim 1 ) and $277 \mathrm{bp}$ (tfap2a) (Table 1). Possibly, this might have influenced the efficiency of the screens since multiple probes were pooled in order to screen the library.

In summary, we were able to obtain a genomic BAC library of $A$. burtoni with a median BAC clone insert size of $150 \mathrm{~kb}$ and an approximate coverage of 14 genome equivalents. Screens of the library using nylon filter sets and radiolabeled genespecific probes corroborate the coverage estimates, although the number of confirmed positives varies between genes. As a rough estimate, an average of $\sim 14.5$ positive clones per screen was obtained. In an attempt to screen for the gene sox $10 b$, we additionally detected its fish-specific paralog sox10a. This shows that BAC libraries serve well to detect paralogous genes.

This BAC library is intended as a genomic resource for the "cichlid community" to facilitate the study of cichlid fishes for evolutionary and genomic purposes. The library is available to the scientific community via the laboratory of Axel Meyer, University of Konstanz, Konstanz, Germany. This library will aid in gaining new insights into the great diversification process in the particular species radiation of haplochromine cichlids.

\section{ACKNOWLEDGMENTS}

We thank Dr. Jing Luo for assisting in the Meyer laboratory, Joshua Danke in particular and the other members of the Amemiya laboratory for helping and assisting M.L. during his time in Seattle. M.L. is grateful to Elvira Juan for providing material and reagents that were required for work during revision of this article. The European Union (Marie Curie Individual Fellowship) and Landesstiftung Baden-Württemberg gGmbH grant was given to W.S., a grant from the National Institutes of Health and National Science Foundation to C.T.A., and grants from the Universität Konstanz and Deutsche Forschungsgemeinschaft to A.M.

\section{LITERATURE CITED}

Albertson RC, Streelman JT, Kocher TD. 2003. Directional selection has shaped the oral jaws of Lake Malawi cichlid fishes. Proc Natl Acad Sci USA 100:5252-5257.

Allender CJ, Seehausen O, Knight ME, Turner GF, Maclean N. 2003. Divergent selection during speciation of Lake Malawi cichlid fishes inferred from parallel radiations in nuptial coloration. Proc Natl Acad Sci 100: 14074-14079.

Amemiya CT, Ota T, Litman GW. 1996. Construction of P1 artificial chromosome (PAC) libraries from lower vertebrates. In: Birren B, Lai E. editors. Non-mammalian genomic analysis: a practical guide. Academic Press, New York. p 223-255.

Barsh GS. 2003. What controls variation in human skin color? PLOS Biol 1:19-22.

Danke J, Miyake T, Powers T, Schein J, Shin H, Bosdet I, Erdmann M, Caldwell R, Amemiya CT. 2004. Genome Resource for the Indonesian Coelacanth Latimeria menadoensis. J Exp Zool 301A:228-234.

Danley PD, Kocher TD. 2001. Speciation in rapidly diverging systems: lessons from Lake Malawi. Mol Ecol 10: 1075-1086.

Dutton KA, Pauliny A, Lopes SS, Elworthy S, Carney TJ, Rauch J, Geisler R, Haffter P, Kelsh RN. 2001. Zebrafish colourless encodes sox10 and specifies non-ectomesenchymal neural crest fates. Development 128:4113-4125.

Feinberg AP, Vogelstein B. 1983. A technique for radiolabeling DNA restriction endonuclease fragments to high specific activity. Anal Biochem 132:6-13.

Francis RC, Soma K, Fernald RD. 1993. Social regulation of the brain-pituitary-gonadal axis. Proc Natl Acad Sci USA 90:7794-7798. 
Fryer G, Iles TD. 1972. The cichlid fishes of the Great Lakes of Africa: their biology and evolution. Edinburgh: Oliver \& Boyd. 641 p.

Fukamachi S, Shimada A, Shima A. 2001. Mutations in the gene encoding $\mathrm{B}$, a novel transporter protein, reduce melanin content in medaka. Nat Genet 28:302.

Gregory TR. 2001. Animal Genomesize Database, URL: http:// www.genomesize.com.

Hinegardner R, Rosen DE. 1968. Evolution of cellular DNA content in teleost fishes. Am Natural 102:517-523.

Hinegardner R, Rosen DE. 1972. Cellular DNA content and the evolution of teleostean fishes. Am Natural 106:621-644.

Hofmann H, Fernald RD. 2000. Social status controls somatostatin neuron size and growth. J Neurosci 20:4740-4744.

Hofmann H, Benson ME, Fernald RD. 1999. Social status regulates growth rate: consequences for life-history strategies. Proc Natl Acad Sci USA 96:14171-14176.

Katagiri T, Asakawa S, Minagawa S, Shimizu N, Hirono I, Aoki T. 2001. Construction and characterisation of BAC libraries for three fish species: rainbow trout, carp and tilapia. Anim Genet 32:200-204.

Klett V, Meyer A. 2002. What, if anything, is a tilapia?Mitochondrial ND2 phylogeny of Tilapiines and the evolution of parental care systems in the African cichlid fishes. Mol Biol Evol 19:865-883.

Knight RD, Nair S, Nelson SS, Afshar A, Javidan Y, Geisler R, Rauch G-J, Schilling TF. 2003. Lockjaw encodes a zebrafish tfap2a required for early neural crest development. Development 130:5755-5768.

Kocher T. 2004. Adpative evolution and explosive speciation: the cichlid fish model. Nat Rev Genet 5:288-298.

Kocher T, Conroy J, McKaye K, Stauffer J. 1993. Similar morphologies of cichlid fish in lakes Tanganyika and Malawi are due to convergence. Mol Phylogenet Evol 2:158-165.

Kocher T, Fernald R, Hofmann H, Meyer A, Okada N, Penman D. 2004. Genome sequence of a cichlid fish: the Tilapia (Oreochromis niloticus). Whitepaper.

Koopman P, Schepers G, Brenner S, Venkatesh B. 2004. Origin and diversity of the Sox transcription factor gene family: genome-wide analysis in Fugu rubripes*1. Gene 328:177-186.

Kumar S, Tamura K, Jakobsen IB, Nei M. 2001. MEGA2: molecular evolutionary genetics analysis software. Bioinformatics 17:1244-1245.

Majumdar KC, McAndrew BJ. 1986. Reative DNA content of somatic nuclei and chromosomal studies in three genera, tilapia, sarotherodon, and oreochromis of the tribe tilapiini (Pisces, Cichlidae). Genetica 68:175-188.

Meyer A. 1993. Phylogenetic relationships and evolutionary processes in East African cichlids. Trends Ecol Evol 8: 279-284.

Meyer A, Kocher TD, Basasibwaki P, Wilson AC. 1990. Monophyletic origin of Lake Victoria cichlid fishes suggested by mitochondrial DNA sequences. Nature 347:550-553.

Meyer A, Kocher T, Wilson A. 1991. Scientific correspondence, African fishes. Nature 350:467-468.

Miyake T, Amemiya CT. 2004. BAC libraries and comparative genomics of aquatic chordate species. Comp Biochem Physiol C 138:233-244.

Ohno S, Atkin NB. 1966. Comparative DNA values and chromosome complements of eight species of fishes. Chromosoma 18:455-466.

Osoegawa K, Woon PY, Zhao B, Frengen E, Minako T, Catanese JJ, deJong PJ. 1998. An improved approach for construction of bacterial artificial chromosome libraries. Genomics 52:1-8.

Parichy DM, Mellgren EM, Rawls JF, Lopes SS, Kelsh RN, Johnson SL. 2000. Mutational analysis of endothelin receptor b1 (rose) during neural crest and pigment pattern development in the zebrafish Danio rerio. Dev Biol 227: 294-306.

Renn SC, Aubin-Horth N, Hofmann H. 2004. Biologically meaningful expression profiling across species using heterologous hybridization to a cDNA microarray. BMC Genom $5: 42$.

Salzburger W, Meyer A. 2004. The species flocks of East African cichlid fishes: recent advances in molecular phylogenetics and population genetics. Naturwissenschaften 91: 277-290.

Salzburger W, Meyer A, Baric S, Verheyen E, Sturmbauer C. 2002a. Phylogeny of the Lake Tanganyika cichlid species flock and its relationship to the Central and East African haplochromine cichlid fish faunas. Syst Biol 51: 113-135.

Salzburger W, Baric S, Sturmbauer C. 2002b. Speciation via introgressive hybridization in East African cichlids? Mol Ecol 11:619-625.

Salzburger W, Mack T, Verheyen E, Meyer A. 2005. Out of Tanganyika: the repeated adaptive radiations of East African cichlid fishes. BMC Evol 21:17.

Sambrook J, Russell DW. 2001. Molecular cloning, a laboratory manual. New York: Cold Spring Harbor Laboratory Press.

Shizuya H, Birren B, Kim U-J, Mancino V, Slepak T, Tachiri Y, Simon M. 1992. Cloning and stable maintenance of 300kilobase fragments of human DNA in Escherichia coli using an F-factor-based vector. Proc Natl Acad Sci USA 89:8794-8797.

Stiassny MLJ, Meyer A. 1999. Cichlids of the Rift Lakes. Sci Am June:64-69.

Streelman JT, Albertson RC, Kocher TD. 2003. Genome mapping of the orange blotch colour pattern in cichlid fishes. Mol Ecol 12:2465-2471.

Strong SC, Ohta Y, Litman GW, Amemiya CT. 1997. Marked improvement of PAC and BAC cloning is achieved using electroelution of pulsed-field-gel-separated partial digests of genomic DNA. Nucleic Acids Res 25:3959-3961.

Taylor JS, Braasch I, Frickey T, Meyer A, Van de Peer Y. 2003. Genome duplication, a trait shared by 22000 species of ray-finned fish. Genome Res 13:382-390.

Terai Y, Morikawa N, Kawakami K, Okada N. 2003. The complexity of alternative splicing of hagoromo mRNAs is increased in an explosively speciated lineage in East African cichlids. Proc Natl Acad Sci USA 100:12798-12803.

Turner GF, Seehausen O, Knight ME, Allender CJ, Robinson RL. 2001. How many species of cichlid fishes are there in African lakes? Mol Ecol 10:793-806.

Verheyen E, Salzburger W, Snoeks J, Meyer A. 2003. Origin of the superflock of cichlid fishes from lake victoria, East Africa. Science 300:325-329.

Vinogradov AE. 1998. Genome size and GC-percent in vertebrates as determined by flow cytometry. Cytometry 31:100-109.

Watanabe M, Kobayashi N, Fujiyama A, Okada N. 2003. Construction of a BAC library for Haplochromis chilotes, a cichlid fish from Lake Victoria. Genes Genet Syst 78: 103-105.

Watanabe M, Kobayashi N, Shin-i T, Horiike T, Tateno Y, Kohara Y, Okada N. 2004. Extensive analysis of ORF 
sequences from two different cichlid species in Lake Victoria provides molecular evidence for a recent radiation event of the Victoria species flock: identity of EST sequences between Haplochromis chilotes and Haplochromis sp. "Redtailsheller". Gene 343:263-269.

Wickler W. 1962. Zur Stammesgeschichte funktionell korrelierter Organ- und Verhaltensmerkmale: Ei-Attrappen und Maulbrüten bei afrikanischen Cichliden. Z Tierpsychol 19:129-164.

Zardoya R, Vollmer DM, Craddock C, Streelman JT, Karl S, Meyer A. 1996. Evolutionary conservation of microsatellite flanking regions and their use in resolving the phylogeny of cichlid fishes (Pisces: Perciformes). Proc R Soc Lond B 263:1589-1598. 